\title{
FISHERY RESOURCES IN THE WEST COAST OF ACEH AFTER TSUNAMI: RESULTS OF THE BOTTOM TRAWL SURVEYS
}

\author{
Wijopriono", Wedjatmiko"), and Suprapto") \\ 1) Research Institute for Marine Fisheries, Muara Baru-Jakarta
}

Received June 23-2006; Received in revised form May 28-2007; Accepted October 12-2007

\begin{abstract}
Investigation on fishery resources in the west coast of Aceh Province was carried out during July until August 2005 and August until September 2006. One of the objectives of the investigation was to determine the state of demersal stock after the area severely hit by tsunami in December 2004. Data were collected through exploratory fishing, using modified shrimp trawl operated on R. V. Bawal Putih I platform. Stations of observation were made to distribute along the continental shelf area. The results show that a total of 117 demersal fish species were found in the study area with Leiognathidae that was the most abundant in both of the years. As for shrimps, a total of 16 species was recorded. Fish densities in 2006 tend to be higher as compared to the densities in 2005. However, statistical comparisons of the abundances between the two years showed no significant difference in the catches of the dominant demersal families. There may be signs of change in shallow water species composition and abundance, probably due to the concentration of effort in the inshore areas (<15 m depth). Conversely, less impacted deeper species show signs of increase.
\end{abstract}

KEYWORDS: fishery resources, trawl survey, Aceh

\section{INTRODUCTION}

The tsunami disaster in December 26, 2004 had a devastating effect on coastal fishing communities in Aceh Province. Along with destroying housing and communities facilities, the tsunami killed an estimated 10.000 fishers and destroyed over 10.000 fishing boats, countless fishing gears and associated support infrastructure (MMAF, 2006).

Before tsunami, the fishing gears used to exploit demersal resources in the west coast consisted of bottom long lines, hand lines, bottom gill nets (including trammel nets) and beach seines. In the coastal southern part of the area off Aceh Selatan, in waters less than $15 \mathrm{~m}$ depth, small bottom trawls are also used. Some of these have recently replaced gill nets. Hand lines are operated on the coral reef area to catch demersal reef fish.

Through aid from international and non governmental organizations, national and local governments, the replacement of boats and gears has been gradually occurred. However, the distribution of these aid varied greatly, with a few villages receiving the bulk of the aid while some villages received none at all. The boats distributed through the aid programme have been mainly smaller type of boats (mostly between 5 and $12 \mathrm{GT}$ ) with respect to the original fleet configuration (Garces et al., 2006). These may have consequences on the overall diversity of the future fishing activities (e.g. gears used, fishing zone, and target species).
There have been a number of efforts to assess the state of the fishery resources in the Aceh area, particularly after the event of tsunami. These information are needed in order to rebuild the fishery sector consistent with the government's goal to rebuild the sector and its management better than the situation before the tsunami. Most of the previous assessments indicated that demersal resources in the area might be over-exploited already since the late 1980s (Bailey et al., 1987). More recent analyses of the trends (OSRO/RAS/504/LAO) indicated declines in catches of all the main groups in later years.

Investigation of fishery resources in the west coast of Aceh Province was carried out during July until August 2005 and August until September 2006, two consecutive years after the area hit by the tsunami. This paper presents the status of demersal stock identification based on the results of the exploratory bottom trawl survey.

\section{MATERIALS AND METHODS}

The R. V. Bawal Putih I was used for conducting the survey of demersal fish both in 2005 and 2006, using a modified shrimp trawl with $36 \mathrm{~m}$ headrope, adapted for demersal fish trawling. The average trawling time in each 
fishing station was one hour with the towing speed of 3 to 3.2 knots. A total of 27 trawl stations were completed, distributed within and between the acoustic transect lines (Figure 1). The catch from each station was sorted and identified to either species or family weighed and counted. Individual fish length and weight of some selected species, were measured for further analysis. Species identification was based on Carpenter \& Niem (1998-2001); Allen (2000); De Bruin et al. (1994); Heemstra \& Randall (1993).

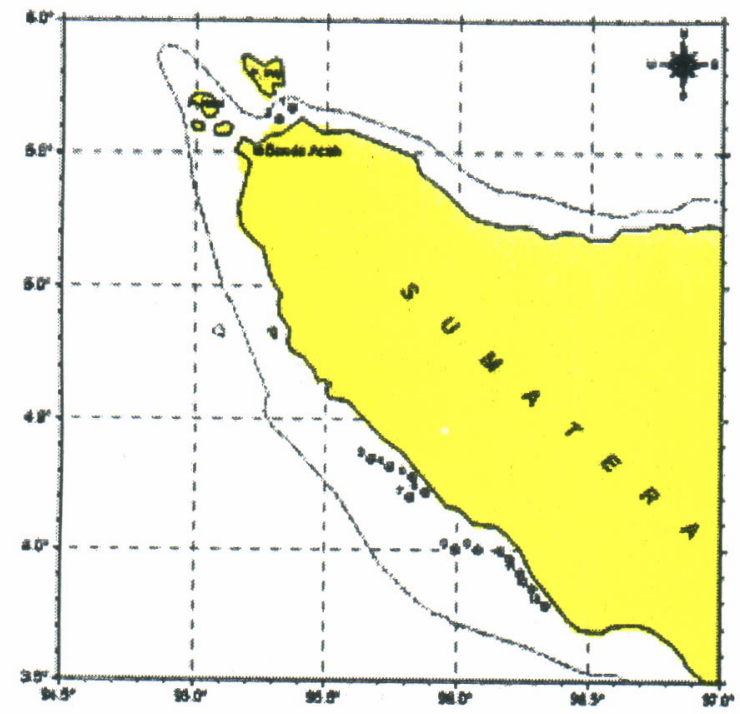

The demersal catch data were standardized to $\mathrm{kg}$ per hour. Individual length of the fish was measured for dominant species. Length frequency samples were weighted to total catch in each trawl haul and pooled to obtain the total length frequency for the population. The catch composition and length frequency were compared with those collected on board of R. V. Bawal Putih I first cruise in 2005. The abundance of demersal fish was calculated using the swept area method.

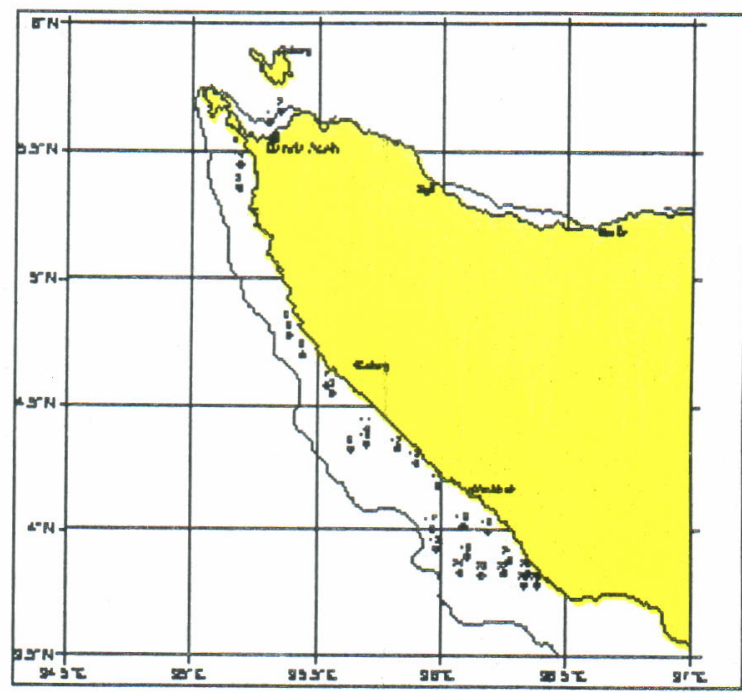

Figure 1. Stations of observation made during bottom trawl survey in 2005 (left) and 2006 (right).

\section{RESULTS AND DISCUSSION}

\section{Species Composition}

\section{Demersal Fish}

A total of 117 demersal fish species were found in the study area with Leiognathidae provide the most abundant, composing 24.3 and $32.5 \%$ of the catches in 2005 and
2006, respectively (Table 1). It had more species in 2006, being represented by 13 species compared to 8 species in 2005. The family was dominated by Leiognathus bindus $(52.4 \%)$, followed by Leiognathus leuciscus (15.5\%). Mullidae was in the second rank (15.2\%) followed by Haemulidae (10.4\%), Sphyraenidae $(7.4 \%)$, and Lutjanidae (6.3\%). Other families contributed of less than $5 \%$ to the total catch.

Table 1. Main demersal fish caught from bottom trawl survey in 2005 and 2006

\begin{tabular}{|c|c|c|c|c|c|c|}
\hline \multirow{2}{*}{ No. } & \multicolumn{3}{|c|}{2005} & \multicolumn{3}{|c|}{2006} \\
\hline & Family & $W(\mathrm{~kg} / \mathrm{hr})$ & $(\%)$ & Family & $W(\mathrm{~kg} / \mathrm{hr})$ & $(\%)$ \\
\hline 1. & Leiognathidae & 9,6 & 24,3 & Leiognathidae & 18,9 & 32,5 \\
\hline 2. & Mullidae & 5,5 & 14,1 & Mullidae & 8,9 & 15,2 \\
\hline 3. & Lutjanidae & 3,3 & 8,4 & Haemulidae & 6,0 & 10,41 \\
\hline 4. & Haemulidae & 2,8 & 7,1 & Sphyraenidae & 4,3 & 7,4 \\
\hline 5. & Synodontidae & 2,5 & 6,3 & Lutjanidae & 3,6 & 6,3 \\
\hline 6. & Nemipteridae & 2,4 & 6,0 & Synodontidae & 2,6 & 4,5 \\
\hline 7. & Trichiuridae & 1,7 & 4,4 & Lactaridae & 2,3 & 3,9 \\
\hline 8. & Tetraodontidae & 1,3 & 3,3 & Nemipteridae & 2,0 & 3,5 \\
\hline 9. & Lactaridae & 1,2 & 3,0 & Gerreidae & 1,7 & 2,8 \\
\hline 10. & Gerreidae & 1,0 & 2,6 & Trichiuridae & 1,1 & 2,0 \\
\hline
\end{tabular}


The relative abundance of the second most dominant family of the Mullidae, was likely similar between the two years. This family was dominated by Upeneus sulphureus, composing $94.4 \%$ of the total mullid catch. The catch of this species was eighty times higher compared to those obtained in 2005 and the statistical test wassignificant difference. The rest of the species included $U$. molluccensis, $U$ sundaicus, $U$. tragula, $U$. vittatus, and Parupeneus spp.

Nemipteridae was represented by 11 species in 2006 , having more species compared to those found in 2005 which was accounted for 7 species. There was a shifting species dominancy in the study area Nemipterus japonicus, which was recorded in the second rank within the family in 2005, has been most dominant in 2006 composing $62.6 \%$ of the total nemipterid catch.

The family of Pomadasydae contributed $5.4 \%$ to the total catch, and was represented by 3 species, i.e. Pomadasys argyreus (94.8\%), Plectorhyncus pictus $(3.8 \%)$, and Pomadasys kaakan (1.6\%).

The Indian halibut (Psettodes erumei) represented 2\% of the catch. This species concentrated in the waters within the depth range of 50 to $59 \mathrm{~m}$. The same result was also obtained by Herianti \& Rusmadji (1992) in waters of the Java Sea. However, Rusmadji \& Nugroho (1987) reported that in the waters of Tanjung Selatan-South Kalimantan the fish tend to be distributed in shallow waters of less than $40 \mathrm{~m}$.

\section{Pelagic Fish}

Pelagic fish are often caught in the bottom trawl. Although biomass estimation of pelagic fish from bottom trawl surveys is usually not carried out because bottom trawl is not appropriate to sample this group, the information on catch rates would be useful to detect major changes in species composition.

Dominant families of the pelagic group are shown in Table 2. These included the Carangidae (53.9\%), Clupeidae (2.9\%), Engraulidae (1.7\%), and others. The family Carangidae was dominated by Carangoides malabaricus $(27.0 \%)$, Scomberomorus commersoni $(8.8 \%)$, Carangoides armatus $(6.4 \%)$, the Clupeidae by Sardinella brachysoma (6.2\%). The family Carangidae provide the dominant species in 2006 . The abundance of this group has increased significantly as compared to 2005 , from $3.5 \mathrm{~kg}$ per $\mathrm{h}$ to $7.5 \mathrm{~kg}$ per $\mathrm{h}$ in 2006.

Table 3 shows a summary of the length frequencies taken for selected demersal and pelagic fish species. Comparisons between the two years are only available for a few dominant species. For all these species the length (mode) observed in 2006 was higher. These species occur mainly at depths of 20 to $40 \mathrm{~m}$. It was likely that fishermen have fished less in these depth ranges in 2006, concentrating more fishing in shallower waters (less than $15 \mathrm{~m}$ ).

Table 2. Pelagic fish caught from bottom trawl surveys in 2005 and 2006

\begin{tabular}{ccccccc}
\hline \multirow{2}{*}{ No. } & \multicolumn{2}{c}{$\mathbf{2 0 0 5}$} & \multicolumn{3}{c}{$\mathbf{2 0 0 6}$} \\
\cline { 2 - 7 } & Family & $\mathbf{W}(\mathbf{k g} / \mathbf{h r})$ & $\mathbf{( \% )}$ & Familiy & $\mathbf{W}(\mathbf{k g} / \mathbf{h r})$ & $(\mathbf{\%})$ \\
\hline 1. & Engraulidae & 3.5 & 47.1 & Carangidae & 7.6 & 54.0 \\
2. & Clupeidae & 1.9 & 26.0 & Clupeidae & 2.9 & 20.5 \\
3. & Carangidae & 1.8 & 23.8 & Engraulidae & 1.7 & 12.0 \\
4. & Scombridae & 0.2 & 2.6 & Scombridae & 1.6 & 11.2 \\
5. & Stromateidae & 0.02 & 0.3 & Stromateidae & 0.3 & 2.2 \\
6. & Chirocentridae & 0.01 & 0.2 & Chirocentridae & 0.01 & 0.1 \\
\hline & Total & $\mathbf{7 . 5}$ & $\mathbf{1 0 0 . 0}$ & Total & $\mathbf{1 4 . 0}$ & $\mathbf{1 0 0 . 0}$ \\
\hline
\end{tabular}


Table 3. Length frequencies of selected demersal and pelagic species

\begin{tabular}{|c|c|c|c|c|c|c|c|c|c|c|}
\hline \multirow{2}{*}{ Species name } & \multicolumn{5}{|c|}{2005} & \multicolumn{5}{|c|}{2006} \\
\hline & Min & Max & Mean & Med. & Mode & $\operatorname{Min}$ & Max & Mean & Med. & Mode \\
\hline Alepes djedaba & & & & & & 10.0 & 19.0 & 12.6 & 14.5 & 12.0 \\
\hline Atule mate & & & & & & 11.0 & 16.5 & 12.3 & 13.8 & 12.5 \\
\hline Carangoides armatus & & & & & & 13.5 & 26.0 & 18.0 & 19.8 & 16.0 \\
\hline Carangoides malabaricus & & & & & & 10.0 & 20.0 & 13.1 & 14.5 & 11.0 \\
\hline Gazza minuta & & & & & & 8.0 & 10.0 & 9.1 & 9.0 & 8.5 \\
\hline Illisha elongata & & & & & & 9.0 & 14.5 & 12.9 & 11.8 & 13.0 \\
\hline Leiognathus equulus & & & & & & 10.0 & 20.0 & 14.0 & 15.0 & 14.0 \\
\hline Leiognathus bindus & 5.5 & 11.5 & 9.2 & 8.5 & 9.5 & 6.0 & 11.5 & 9.4 & 8.8 & 10.0 \\
\hline Leiognathus daura & & & & & & 5.0 & 10.5 & 7.8 & 8.3 & 7.5 \\
\hline Leiognathus elongatus & & & & & & 8.0 & 12.5 & 10.0 & 10.3 & 10.0 \\
\hline Leiognathus fasciatus & & & & & & 13.5 & 20.0 & 16.7 & 16.8 & $18,17,20$ \\
\hline Leiognathus smithursti & & & & & & 11.0 & 16.0 & 13.5 & 13.5 & 14.0 \\
\hline Lutjanus lutjanus & & & & & & 12.0 & 19.5 & 15.9 & 15.8 & 16.5 \\
\hline Megalaspis cordyla & & & & & & 15.5 & 24.5 & 18.7 & 20.0 & 16.5 \\
\hline Nemipterus tolu & 2.5 & 13.0 & 6.2 & 7.8 & 3.5 & 16.0 & 22.0 & 19.3 & 19.0 & $18,19,20,20.5$ \\
\hline Parupenaeus sp. & & & & & & 13.0 & 26.5 & 20.6 & 19.8 & $20.5,21,26.5$ \\
\hline Pentaprion longimanus & & & & & & 9.0 & 12.5 & 10.2 & 10.8 & 9.5 \\
\hline Polydactylus & & & & & & 10.0 & 19.5 & 14.0 & 14.8 & 13.5 \\
\hline Pomadasys argyreus & 5.0 & 17.5 & 10.6 & 11.3 & 9.5 & 6.0 & 19.5 & 11.6 & 17.0 & 10.5 \\
\hline Pristipomoides filamentosus & & & & & & 10.0 & 24.0 & 16.6 & 17.0 & 14.0 \\
\hline Rastrelliger brachysoma & & & & & & 13.5 & 17.0 & 15.5 & 15.3 & $15.5,16.5$ \\
\hline Rastrelliger kanagurta & & & & & & 13.0 & 16.0 & 15.0 & 14.5 & 16.0 \\
\hline Saurida micropectoralis (TL) & & & & & & 24.0 & 37.0 & 30.3 & 30.5 & 31,34 \\
\hline Sciaena sp. & & & & & & 18.0 & 21.5 & 19.1 & 19.8 & 18.5 \\
\hline Selar crumenolpthalmus & & & & & & 15.0 & 17.0 & 16.4 & 16.3 & 17.0 \\
\hline Sphyraena sp. & & & & & & 22.0 & 28.0 & 24.1 & 25.0 & 23.0 \\
\hline Thryssa sp. & & & & & & 6.0 & 15.0 & 10.6 & 12.8 & 10.0 \\
\hline Upeneus mollucensis & & & & & & 9.5 & 16.0 & 12.4 & 12.8 & 14.5 \\
\hline Upeneus sulphureus & 1.5 & 14.5 & 8.8 & 8 & 8.5 & 8.5 & 15.0 & 10.2 & 11.8 & $9.5,10.5$ \\
\hline Upeneus vittatus & & & & & & 15.5 & 19.5 & 18.1 & 17.5 & $17.5,19.5$ \\
\hline Uraspis uraspis & & & & & & 6.0 & 9.5 & 8.3 & 7.8 & 9.0 \\
\hline
\end{tabular}

\section{Crustaceans}

The crustaceans are divided into 3 groups; 1) shrimps of economic importance; 2) shrimps of non economic importance; and 3) other crustaceans that mainly consisted of crabs). The total catches were dominated by shrimps of economic importance $(86.3 \%)$ followed by shrimps of non economic importance (10.9\%) and other crustaceans (3.5\%).
While catch rates for all shrimps have remained at the same level, it was likely that changes in species composition occurred, with a higher diversity in 2005 as compared to 2006. Furthermore, while Penaeus sp. species made up almost $80 \%$ of the catches in 2005 , the endeavour shrimp (Metapenaeus ensis) was almost $50 \%$ of the catches in 2006 (Tabel 4). This species caught in deeper waters than Penaeus sp., and this pattern was due to the fact that fishing effort in 2006 were concentrated in shallower waters. 


\begin{tabular}{|c|c|c|c|c|c|c|}
\hline \multirow{2}{*}{ No. } & \multicolumn{3}{|l|}{2005} & \multicolumn{3}{|c|}{2006} \\
\hline & Species & W (kg/hr) & $(\%)$ & Species & $\mathrm{W}(\mathrm{kg} / \mathrm{hr})$ & $(\%)$ \\
\hline 1. & Penaeus sp. & 0,48 & 40,7 & Metapenaeus ensis & 0,48 & 49,8 \\
\hline 2. & Penaeus semisulcatus & 0,26 & 27,4 & Penaeus sp. & 0,23 & 23,6 \\
\hline 3. & Penaeus merguiensis & 0,09 & 9,8 & Solenocera crassicornis & 0,09 & 9,0 \\
\hline 4. & Metapenaeus ensis & 0,08 & 9,0 & Parap. coromandelica & 0,08 & 8,6 \\
\hline 5. & Metapenaeus affinis & 0,03 & 3,2 & Penaeus semisulcatus & 0,07 & 7,2 \\
\hline 6. & Penaeus monodon & 0,02 & 1,8 & Metapenaeus spp. & 0,02 & 1,6 \\
\hline 7. & Solenocera crassicornis & 0,02 & 1,7 & Metapenaeopsis toloensis & 0,002 & 0,2 \\
\hline 8. & Metapenaeus dobsoni & 0,01 & 1,5 & Exopalaemon styliferus & 0,001 & 0,1 \\
\hline 9. & Penaeus canaliculatus & 0,01 & 1,3 & & & \\
\hline 10. & Parapenaeopsis spp. & 0,01 & 1,0 & & & \\
\hline 11. & Exopalaemon styliferus & 0,01 & 0,9 & & & \\
\hline 12. & Metapenaeopsis barbata & 0,01 & 0,7 & & & \\
\hline 13. & Metapenaeopsis toloensis & 0,01 & 0.7 & & & \\
\hline 14. & Parap. coromandelica & 0,002 & 0,2 & & & \\
\hline 15. & Trachypenaeus spp. & 0,001 & 0,2 & & & \\
\hline \multirow[t]{2}{*}{16.} & Metapenaeus spp. & 0,000 & 0,02 & & & \\
\hline & Total & 0,94 & 100,0 & Total & 0,96 & 100,0 \\
\hline
\end{tabular}

\section{Fish Density}

Table 5 shows catch rates by main groups. Demersal fish dominated the catches both in 2005 and 2006, representing about $75 \%$ of the total catch. Catch rates of the demersal group were found to be higher in 2006 compared to those for 2005 . The same figures were also showed for crustaceans, pelagic, and cephalopods groups. It was likely that change in species composition and abundance in shallow waters were occurred. These were probably due to concentration of effort in the inshore areas. Conversely, some deeper species that are likely less impacted by exploitation show signs of population growth as reflected by the higher catch rate (Figure 2).

Fish densities in 2006 were higher as compared to 2005. However, the density was not statistically significant different between the two years, except for the pelagic group. Statistical comparisons of abundances between the two years showed no significant difference in the catches of the dominant demersal families (Table 6 ).

Table 5. Comparison of catch rates by main groups between 2005 and 2006

\begin{tabular}{clcccc}
\hline \multirow{2}{*}{ No. } & \multicolumn{2}{c}{ Groups } & \multicolumn{2}{c}{$\mathbf{2 0 0 5}$} & \multicolumn{2}{c}{ 2006 } \\
\cline { 3 - 6 } & & $\begin{array}{r}\text { Weight } \\
\text { (kg/hr) }\end{array}$ & Percentage (\%) & $\begin{array}{c}\text { Weight } \\
\text { (kg/hr) }\end{array}$ & Percentage (\%) \\
\hline 1. & Demersal & 39.3 & 75.4 & 58.2 & 76.8 \\
2. & Pelagic & 7.5 & 14.3 & 14.0 & 18.5 \\
3. & Rays & 3.6 & 6.9 & 0.9 & 1.2 \\
4. & Crustaceans & 1.1 & 2.2 & 1.6 & 2.2 \\
5. & Cephalopods & 0.4 & 0.8 & 0.7 & 0.9 \\
6. & Bivalves & 0.2 & 0.3 & 0.1 & 0.2 \\
7. & Sharks & 0.07 & 0.1 & 0.2 & 0.3 \\
8. & Sea cucumber & 0.02 & 0.04 & - & - \\
\hline
\end{tabular}



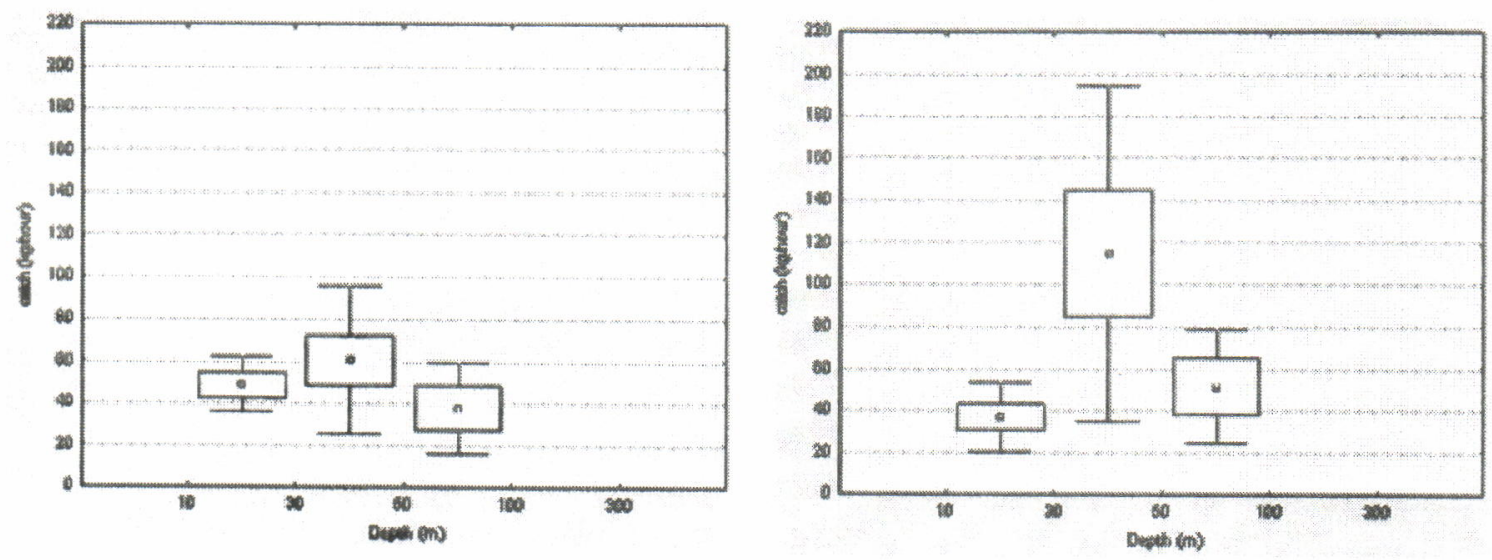

Figure 2. Catch rates by depth area in the west coast of Aceh waters in 2005 (a) and 2006 (b).

Table 6.

Catch rates from Bawal Putih testing for differences between 2005 (group 1) and 2006 (group 2) using non parametric Man Whitney $U$ tests

Tests by groups

\begin{tabular}{|c|c|c|c|c|c|c|c|c|c|c|}
\hline \multirow[t]{2}{*}{ variable } & \multicolumn{10}{|c|}{$\begin{array}{c}\text { Mann-Whitney U Test (catch rate group-ache) } \\
\text { By variable Year } \\
\text { Marked tests are significant at } p<.05000\end{array}$} \\
\hline & $\begin{array}{l}\text { Rank Sum } \\
\text { Group } 1\end{array}$ & $\begin{array}{c}\text { Rank Sum } \\
\text { Group } 2\end{array}$ & U & $Z$ & p-level & $\begin{array}{c}\frac{1}{2} \\
\text { acjusted }\end{array}$ & p-level & $\begin{array}{l}\text { Valid N } \\
\text { Group } 1\end{array}$ & $\begin{array}{l}\text { Valid N } \\
\text { Group } 2\end{array}$ & $\begin{array}{l}2^{*} 1 \text { sided } \\
\text { exact } p\end{array}$ \\
\hline SHARK & 391.0000 & 512.0000 & 212.0000 & 0.10167 & 0.919022 & 0.19959 & 0.841801 & 18 & 24 & 0.929901 \\
\hline RAYS & 88.0000 & 100 & 165.0000 & 1.29624 & 0.194895 & 1.67611 & 0.093718 & 18 & 24 & 0.201622 \\
\hline PELAGIC & 306.0000 & 000 & 135.0000 & -2.05873 & 0.039521 & -2.05873 & 0.039521 & 18 & 24 & 0.039821 \\
\hline DEMERSAL & 369.0000 & .0000 & 198.0000 & -0.45750 & 0.647315 & -0.45750 & 0.647315 & 18 & 24 & 0.659828 \\
\hline CHEPALOPOD & 6.5000 & 6.5000 & 185.5000 & -0.77520 & 0.438221 & -0.77596 & 0.437776 & 18 & 24 & 341 \\
\hline SHRIMP & 0.0000 & 503.0000 & 203.0000 & 0.33041 & 0.741088 & 0.33267 & 0.739382 & 18 & 24 & 0.753306 \\
\hline CRABS & 320.0000 & 583.0000 & 149.0000 & -1.70290 & 0.088588 & -1.78762 & 0.0 & 18 & 24 & 169 \\
\hline MANTIS & 330.0000 & 573.0000 & 159.0000 & -1.44874 & 0.147412 & -1.56578 & 0.117402 & 18 & 24 & 0.152461 \\
\hline LOBSTER & 391.5000 & 511.5000 & 211.5000 & 0.11437 & 0.908941 & 0.13963 & 0.888950 & 18 & 24 & 0.909946 \\
\hline SHELL & 402.0000 & 501.0000 & 201.0000 & 0.38125 & 0.703021 & 0.47820 & 0.632506 & 18 & 24 & 0.715399 \\
\hline Grand Total & 352.0000 & 551.0000 & 181.0000 & -0.88957 & 0.373695 & -0.88957 & 0.373695 & 18 & 24 & 0.384556 \\
\hline
\end{tabular}

Tests by family

\begin{tabular}{|c|c|c|c|c|c|c|c|c|c|c|}
\hline \multirow[t]{2}{*}{ variable } & \multicolumn{10}{|c|}{$\begin{array}{c}\text { Mann-ihhitney U Test (catch rate famihy-ache) } \\
\text { By variable yarar } \\
\text { Wuarked tests ane significant at } p<.05000\end{array}$} \\
\hline & $\begin{array}{l}\text { Rank Sum } \\
\text { Group } 1\end{array}$ & $\begin{array}{c}\text { Rank Sum } \\
\text { Group } 2\end{array}$ & $\mathrm{U}$ & $\bar{z}$ & p-level & $\begin{array}{c}Z \\
\text { adjusted }\end{array}$ & p-leval & $\begin{array}{l}\text { Walid N } \\
\text { Group } 1\end{array}$ & $\begin{array}{l}\text { Walid N } \\
\text { Group } 2\end{array}$ & $\begin{array}{l}2^{*} 1 \text { sided } \\
\text { axalet } \mathrm{p}\end{array}$ \\
\hline [Other crabs] & 20.0000 & 16.0000 & 5.0000 & .0 .74536 & 0.456057 & $=0.74536$ & 0.456057 & 5 & 3 & 0.571429 \\
\hline Acanthuridae & & & 0.0000 & 0.00000 & 1.000000 & 0.00000 & 1.000000 & 1. & 3 & 0.000000 \\
\hline Apugonidae & 139.5000 & 50.5000 & 14.5000 & 2.43588 & 0.014850 & 2.44880 & 0.014334 & 11 & 8 & 0.012068 \\
\hline Avidae & 18.0000 & 18.0000 & 8.0000 & 0.00000 & 1.000000 & 0.00000 & 1.000000 & 4 & 4 & 1.000000 \\
\hline Balistidae & 29.0000 & 26.0000 & 8.0000 & -0.85280 & 0.393769 & -0.85802 & 0.390883 & 6 & 4 & 0.476190 \\
\hline Blennidae & & & 0.0000 & 0.00000 & 1.000000 & 0.00000 & 1.000000 & 0 & D & 0.000000 \\
\hline Bothidae & 126.0000 & 45.0000 & 30.0000 & 0.24643 & 0.805348 & 0.24784 & 0.804256 & 13 & 5 & 0.848973 \\
\hline Carangidae & 275.0000 & 586.0000 & 122.0000 & -2.16995 & 0.030011 & -2.17023 & 0.029990 & 17 & 24 & 0.029899 \\
\hline Calagpidae & & & 0.0000 & 0.00000 & 1.000000 & 0.00000 & 1.000000 & D & D & 0,000000 \\
\hline Carcharhinidae & & & 0.0000 & 0.00000 & 1.000000 & 0.00000 & 1.000000 & 1 & 1 & 0.000000 \\
\hline Centridase & & & 0.0000 & 0.00000 & 1.000000 & 0.00000 & 1.000000 & 0 & D & 0.000000 \\
\hline Chaetodontidae & & & 0.0000 & 0.00000 & 1.000000 & 0.00000 & 1.000000 & 2 & $D$ & 0.000000 \\
\hline Chirocentridae & & & 0.0000 & 0.00000 & 1.000000 & 0.00000 & 1.000000 & 1 & 1 & 0.000000 \\
\hline Clupeidae & 228.0000 & 300.0000 & 110.0000 & 0.51799 & 0.604488 & 0.51799 & 0.604468 & 13 & 19 & 0.622762 \\
\hline Congridae & & & 0.0000 & 0.00000 & 1.000000 & 0.00000 & 1.000000 & 2 & 0 & 0.000000 \\
\hline Cynoglossidae & 64.0000 & 41.0000 & 13.0000 & 1.46942 & 0.141721 & 1.48918 & 0.136440 & 7 & 7 & 0.164918 \\
\hline Dasyatidae & 46.0000 & 20.0000 & 10.0000 & 0.75593 & 0.449692 & 0.75593 & 0.448692 & 7 & 4 & 0.527273 \\
\hline Diodontidae & & & 0.0000 & 0.00000 & 1.000000 & 0.00000 & 1.000000 & 1 & 1 & 0.000000 \\
\hline Dactulopteridae & & & 0.0000 & 0.00000 & 1.000000 & 0.00000 & 1.000000 & D. & 0 & D. .0000000 \\
\hline Bopidae & & & 0.0000 & O..0OOOOO & 1.000000 & 0.00000 & 1.000000 & D & D & 0.000000 \\
\hline Engraulidae & 237.5000 & 227.5000 & 107.5000 & 0.20739 & 0.835705 & 0.20751 & 0.835615 & 15 & 15 & 0.838135 \\
\hline Ephippidze & 45.0000 & 81.0000 & 17.0000 & -1.53484 & 0.124823 & -1.53597 & 0.124546 & 7 & 9 & 0.141608 \\
\hline Fistulariidae & 81.0000 & 80.0000 & 36.0000 & -0.39736 & 0.691103 & -0.39860 & 0.690191 & 9 & 8 & 0.730440 \\
\hline
\end{tabular}




\section{CONCLUSION}

Based on the results of these investigations, the following conclusions can be drawn:

1. Based on the results of the demersal surveys carried out after the tsunami did not show any major change in total fish abundance between 2005 and 2006.

2. The pelagic fish found in the demersal trawl catches was the only group showing a statistically significant increase in 2006 compared to 2005, with Carangidae provide the most dominant family.

3. The change in shallow water species composition and abundance were probably due to concentration of effort in the areas. Conversely, some deeper species that are likely less impacted by exploitation show signs of population growth.

\section{ACKNOWLEDGEMENTS}

This paper is based on the results of joint research between Norway-Indonesia, in 2005 and 2006 (Research Centre for Oceanography-Indonesian Institute of Sciences and Research Centre for Capture Fisheries).

\section{REFERENCES}

Allen, G. 2000. Marine fishes of south east Asia. Western Australian Museum. 1999.

Bailey, C., A. Dwiponggo, \& F. Marahudin. 1987. Indonesian marine capture fisheries. Manila: International Centre for Living Aquatic Resources Management.
Carpenter, K. E. \& V. H. Niem. 1998-2001. The living marine reources of the western centrak Pacific. Vol.16. FAO Species Identification Guide for Fishery Purposes. FAO. Rome.

De Bruin, G. H. P., B. C. Russell, \& A.Bogusch. 1994. FAO species identification guide for fishery purposes. The Marine Fishery Resources of Sri Lanka. Food and Agriculture Organization of the United Nations. Rome. 1994.

Garces, L., A. Tewfic, M. Pido, N. Fatan, D. Adhuri, N. Andrew, \& M. Dey. 2006. Fisheries rehabilitation in post tsunami Aceh: status and needs from participatory appraisals. Naga. 29(3): 19-30.

Heemstra, P. C. \& J. E. Randall. 1993. FAO species catalogue. Vol.16. Groupers of the World (Family Serranidae, Subfamily Epinephelinae). Food and Agriculture Organization of the United Nations. Rome. 1993.

Herianti, I. \& Rusmadji. 1992. Catch rate, distribution, and biological aspect of indian halibut (Psettodes erumei) in the north coast of Java. Journal of Marine Fisheries Researh. No.75. 1992. 45-53 pp.

Ministry of Marine Affairs and Fisheries, Republic of Indonesia. 2006. Country report: Republic of Indonesia. Strategy and Program for Rehabilitation and Reconstruction of the Fishery Sector in Aceh and Nias: Post Earthquake and Tsunami Wave Disaster.

Rusmadji \& D. Nugroho. 1987. Maturity, sex ratio, and length weight relationship of indian halibut (Psettodes erumel) in Tanjung Selatan waters south Kalimantan. Journal of Marine Fisheries Researce. No.38. 1987. 69-76 pp. 
